Vol. 24, No. 3, Juli 2021, hlm. 521-532

p-ISSN: 1410-9344; e-ISSN: 2549-5631

WARTA LPM

homepage: http://journals.ums.ac.id/index.php/warta

\title{
Penyuluhan Literasi Keuangan pada Ibu Rumah Tangga di Depok Sebagai Dasar Membangun Ketahanan Keuangan Keluarga
}

\author{
Lindiawatie, Dhona Shahreza \\ Universitas Indraprasta PGRI Jakarta, \\ lindiawatie@ymail.com,denzanoena@gmail.com
}

\section{Article Info}

Submitted: 15 January 2021

Revised: 28 April 2021

Accepted: 6 June 2021

Published: 20 July 2021

Keywords: Financial Literacy, Housewive, Financial Resilience, Family.
Kata kunci: Literasi Keuangan, Ibu Rumah Tangga, Ketahanan Keuangan, Keluarga.

\begin{abstract}
The Financial Services Authority's survey in 2016 and 2019 obtained data showing that the financial literacy index of women is low compared to men. Whereas financial literacy is the 21st century life skill that must be mastered by individuals and society in order to achieve a better standard of living. This community service activity aims to equip housewives with financial literacy so that family financial resilience can be realized. The method is counseling accompanied by interactive discussions. The target is housewives in RW 08 Abadijaya, Depok, West Java. Problems that arise during the discussion are the problem of attitudes and financial behavior of their children who are university students, students and single youth in the form of excessive spending behavior, do not understand correct financial planning and do not understand the priority scale of primary, secondary and tertiary needs. The team provides solutions about the correct meaning of money, discipline in saving and the need to make proper financial planning in order to achieve individual and family financial resilience. This community service has opened the minds and awareness of housewives about the importance of financial literacy in family life. Because financial literacy is the basis for building family financial resilience.
\end{abstract}

Abstrak
Survei literasi keuangan Otoritas Jasa Keuangan tahun 2016 dan 2019
diperoleh data yang memperlihatkan indeks literasi keuangan wanita
tergolong rendah dibandingkan dengan laki-laki. Padahal literasi
keuangan merupakan kecakapan hidup abad 21 yang harus dikuasai
individu dan masyarakat supaya tercapai taraf hidup yang lebih baik.
Kegiatan pengabdian masyarakat ini bertujuan untuk membekali ibu
rumah tangga dengan literasi keuangan supaya terwujud ketahanan
keuangan keluarga. Metode pelaksanaan dengan penyuluhan disertai
diskusi interaktif. Sasarannya adalah kalangan ibu-ibu rumah tangga
di RW 08 Abadijaya, Depok, Jawa Barat. Persoalan yang timbul
saat diskusi adalah persoalan sikap dan perilaku keuangan anak-


anak mereka yang berstatus mahasiswa, pelajar, dan pemuda lajang berupa perilaku pembelanjaan yang berlebihan, belum memahami perencanaan keuangan yang benar, dan belum paham skala prioritas kebutuhan primer, sekunder, dan tersier. Tim memberikan solusi tentang makna uang yang benar, disiplin menabung, dan perlunya membuat perencanaan keuangan yang benar supaya tercapai ketahanan keuangan individu dan keluarga. Abdimas ini telah membuka pemikiran dan kesadaran para ibu rumah tangga akan pentingnya literasi keuangan dalam kehidupan keluarga. Karena literasi keuangan adalah dasar membangun ketahanan keuangan keluarga.

\section{PENDAHULUAN}

Perkembangan Kodya Depok sebagai daerah penyangga Ibukota Jakarta mengalami kemajuan yang signifikan sejak diresmikan menjadi Kota Madya pada tahun 1999. Kemajuan tersebut diawali dengan kehadiran berbagai perguruan tinggi negeri maupun swasta yang memicu bergeraknya perekonomian ke arah lebih maju. Dampaknya adalah banyaknya pengembang yang membuat komplek perumahan sebagai pilihan bagi mereka yang berminat bermukim di Depok. Hal tersebut memicu dibangunnya fasilitas-fasilitas pendukung lainnya seperti pusat-pusat perbelanjaan besar, kantor cabang atau perwakilan institusi keuangan, rumah sakit berskala besar, dan menjamurnya restoran dari berbagai ukuran mulai dari skala mikro hingga restoran ternama multinasional.

Kemajuan perekonomian Ibukota Jakarta memberi efek positif dan negatif bagi warga Depok yang berimbas pada perilaku dan gaya hidup warga Depok yang sebagian besar bekerja di Ibukota Jakarta. Fasilitas dan infrastruktur sebuah kota mengubah gaya hidup warga masyarakat sebagaimana didukung oleh penelitian bahwa perubahan bentuk sarana-prasarana dan infrastruktur mengikuti kebutuhan dan gaya hidup perkotaan seperti yang dialami oleh kaum urban yang menjadi warga di Kampung Kota Kebon Kacang, Jakarta, dan Kampung Kukusan, Depok (Sihombing, Rahardja, \& Gabe, 2020). Berbagai fasilitas dan sarana prasarana yang banyak tersedia dan mudah didapat membuat perubahan gaya hidup warga Depok menjadi cenderung konsumtif dalam membelanjakan pendapatannya. Perilaku konsumsi yang tidak proporsional dapat membawa persoalan keuangan dalam rumah tangga di mana terjadi pola pengeluaran lebih besar pasak daripada tiang yang mengakibatkan defisit keuangan rumah tangga. Riset oleh Adzkiya (2018) menemukan hubungan positif antara perilaku konsumtif dan gaya hidup. Riset lain juga menemukan fakta yang sama bahwa kelas menengah perkotaan di Indonesia cenderung mempertimbangkan nilai simbolis dan tekanan sosial sebagai faktor penentu yang penting saat membeli produk daripada nilai guna dan nilai tukarnya (Suyanto, Sugihartati, Hidayat, \& Subiakto, 2020).

Bijak dalam membelanjakan pendapatan merupakan bagian dari program pemerintah untuk mendorong masyarakat supaya mau memanfaatkan lembaga-lembaga keuangan bank dan non bank untuk mempercayakan pengelolaan keuangan mereka. Kemampuan masyarakat membelanjakan pendapatannya secara tepat dan proporsional pada lembaga yang tepat sebenarnya ikut berperan menggerakkan pembangunan ekonomi. Kenyataan tersebut merupakan salah satu dari program strategis Otoritas Jasa Keuangan yang mengarahkan masyarakat untuk memelihara sikap dan perilaku keuangan yang bijak. Terdapat dua program inisiatif yang ingin dicapai yaitu 1) Mewujudkan masyarakat yang memiliki tujuan dan perencanaan keuangan, 2) Mampu mengelola keuangan dengan bijak. Sasarannya adalah pelajar/mahasiswa/pemuda, perempuan, karyawan, profesi, pelaku usaha mikro, kecil, dan menengah, pensiunan, petani, nelayan, penyandang disabilitas, tenaga kerja Indonesia, dan masyarakat daerah terpencil/ terluar (OJK, 2017).

Pada kehidupan rumah tangga, tugas wanita sebagai ibu rumah tangga adalah mengelola 
keuangan rumah tangga dan bertanggungjawab mendidik sikap termasuk perilaku keuangan anak-anak supaya melek keuangan. Survei dari Otoritas Jasa Keuangan pada 2016 menemukan data terkait pemahaman wanita tentang keuangan secara umum tergolong rendah hanya $22,5 \%$ dibandingkan pria sebesar 33,2\% (OJK, 2016). Pada survei 2019 indeks literasi keuangan wanita meningkat menjadi $30,53 \%$ sedangkan indeks keuangan laki-laki meningkat menjadi 43,46\%. Meski ada kenaikan sebesar $8,03 \%$, tetapi pemahaman wanita terkait keuangan masih rendah dibanding laki-laki (OJK, 2019).

Berdasarkan kenyataan itulah maka tim abdimas Universitas Indraprasta PGRI Jakarta (Unindra) berupaya membantu menggiatkan program Otoritas Jasa Keuangan dalam meningkatkan literasi dan inklusi keuangan bagi kaum perempuan umumnya. Tim Abdimas Unindra perlu berpartisipasi mendorong kaum perempuan agar memiliki kecakapan dan keterampilan tentang keuangan khususnya dasar-dasar`pengelolaan keuangan dan pentingnya pengelolaan keuangan yang baik. Dengan demikian diharapkan akan muncul perilaku keuangan yang benar. Apabila perilaku keuangan sudah dipahami maka mudah bagi mereka mengetahui literasi keuangan. Penelitian yang dilakukan oleh Rahmayanti, Nuryani, \& Salam (2019) pada kelompok ibu rumah tangga menunjukkan literasi keuangan dipengaruhi oleh perilaku keuangan.

Pada tahun 2017 Otoritas Jasa Keuangan merevisi program literasi keuangan dengan menambahkan pentingnya aspek sikap dan perilaku keuangan masyarakat. Alasan yang mendasarinya adalah program literasi keuangan dengan pendekatan pengetahuan tidak akan berpengaruh tanpa mengubah sikap dan perilaku keuangan masyarakat. Dengan memiliki sikap dan perilaku keuangan yang bijak, diharapkan masyarakat memiliki tujuan dan perencanaan keuangan serta mengelola keuangan secara benar untuk mencapai kesejahteraan mereka (OJK, 2017). Definisi literasi keuangan menurut Otoritas Jasa Keuangan (2019) adalah pengetahuan, keterampilan, dan keyakinan yang mempengaruhi sikap dan perilaku untuk meningkatkan kualitas pengambilan keputusan dan pengelolaan keuangan dalam rangka mencapai kesejahteraan (OJK, 2019).

Literasi keuangan adalah pengetahuan dan kecakapan untuk mengaplikasikan pemahaman tentang konsep dan risiko, keterampilan agar'dapat membuat keputusan yang efektif dalam konteks keuangan untuk meningkatkan kesejahteraan keuangan, baik individu maupun sosial dan dapat berpartisipasi dalam lingkungan masyarakat. Literasi keuangan merupakan kecakapan hidup abad 21 yang harus dikuasai individu dan masyarakat supaya tercapai kualitas dan taraf hidup yang lebih baik (Kemendikbud, 2017).

Dimensi-dimensi yang terkandung dalam literasi keuangan meliputi memiliki pengetahuan keuangan dan mampu menerapkannya, kecakapan, dan keterampilan dalam mengambil keputusan terkait keuangan dan masalah yang dihadapi, memahami infomasi keuangan serta sikap dan perilaku menyikapi keuangan (Potrich, Viera, \& Kirch, 2014). Sedangkan program strategis Otoritas Jasa Keuangan memiliki tiga sasaran penting yaitu, 1) Cakap keuangan, menginginkan kesadaran, dan pemahaman masyarakat tentang lembaga, produk, dan jasa keuangan, 2) Sikap dan perilaku keuangan yang bijak, menginginkan masyarakat memiliki ketahanan keuangan yang kuat saat mengalami goncangan ekonomi, 3) Akses keuangan, meningkatkan produk, dan layanan jasa keuangan masyarakat (OJK, 2017).

Pada sasaran kedua dari program strategis Otoritas Jasa Keuangan menginginkan dibangunnya ketahanan keuangan di masyarakat. Ketahanan keuangan adalah kemampuan individu untuk mengakses dan memanfaatkan kemampuan internal serta sumber daya eksternal yang sesuai, dapat diterima, dapat diakses serta mendukung saat individu atau keluarga mengalami kesulitan keuangan (Salignac, F, Marjolin, \& Reeve, 2019). Terdapat empat komponen konsep ketahanan keuangan menurut (Salignac, F, Marjolin, \& Reeve, 2019) yaitu : 1) Sumber daya ekonomi; komponen sumber daya ekonomi mencakup berbagai faktor terkait uang yang dapat mempengaruhi kemampuan seseorang untuk mengatasi kesulitan keuangan, termasuk pendapatan, tabungan, pengelolaan keuangan, dan kemampuan untuk memenuhi 
biaya, pengeluaran, dan mengumpulkan dana dalam keadaan darurat. 2) Produk dan layanan keuangan; komponen ini mencakup kemampuan individu mengakses produk dan jasa keuangan bank dan non-bank, seperti kepemilikan rekening di bank, asuransi, dana pensiun, investasi, dan pembiayaan yang benar. Dan 3) Pengetahuan dan perilaku keuangan; ini terlihat dari tingkat pengetahuan dan kepercayaan penggunaan produk dan layanan keuangan, saran keuangan serta perilaku keuangan yang proaktif. Kemampuan ini penting diketahui karena jika individu memiliki pengetahuan dan perilaku keuangan yang tinggi akan mampu mengidentifikasi produk dan layanan yang tepat sehingga efektif mengelola keuangan mereka. 4) Modal sosial; komponen modal sosial termasuk komponen yang penting bagi individu untuk mengatasi goncangan keuangan. Tidak hanya teman, saudara, koneksi komunitas dapat memberikan dukungan di saat-saat kesulitan keuangan. Akses, layanan serta dukungan masyarakat dan pemerintah juga membantu ketahanan keuangan bagi rumah tangga atau golongan masyarakat berpendapatan rendah.

Faktor-faktor yang menentukan ketahanan keuangan bukan dari penghasilan melainkan dari kemampuan individu mengakses aset likuid dan dana darurat, kemampuan untuk meminjam dengan harga yang wajar, sikap individu dalam merespon goncangan keuangan, jaringan keluarga dan literasi keuangan (McKnight, 2018). Ketahanan keuangan keluarga merupakan bagian dari upaya pemerintah dalam rangka membangun ketahanan ekonomi keluarga. Keluarga merupakan unit terkecil yang berperan penting dalam proses pembangunan. Keluarga merupakan unit/institusi/sistem sosial terkecil dalam masyarakat yang beranggotakan sekelompok orang atas dasar hubungan perkawinan, pertalian darah dan adopsi yang tinggal bersama dalam sebuah rumah tangga (KPPPA, 2016). Ketahanan keuangan termasuk salah satu variabel dari ketahanan ekonomi keluarga yang dirumuskan oleh KPPPA yaitu adanya jaminan keuangan keluarga yang diukur dari indikator tabungan dan perlindungan kesehatan. Ketahanan keuangan ini menjadi penting dimiliki oleh keluarga atau individu untuk menghadapi goncangan keuangan dan kejadian yang tidak terduga seperti sakit keras, pemutusan hubungan kerja, kecelakaan, atau meninggal dunia. Karakteristik keluarga ada empat yaitu; 1) Tersusun dari beberapa orang yang disatukan dengan ikatan perkawinan, hubungan darah, dan adopsi, 2) Hidup dan menetap bersama-sama di bawah satu atap atau bangunan di suatu tempat dalam suatu rumah tangga, 3) Setiap anggota keluarga berinteraksi, berkomunikasi, dan menciptakan peran sosial seperti suami dan istri, ayah dan ibu, putera dan puteri, dan saudara laki-laki dan perempuan, dan 4) Hubungan antar anggota keluarga merupakan representasi upaya pemeliharaan pola-pola kebudayaan bersama yang diperoleh dari kebudayaan umum di komunitas (KPPPA, 2016).

Mengingat bahwa permasalahan rendahnya literasi keuangan di kalangan wanita berdampak pada rendahnya pemanfaatan jasa lembaga keuangan bank dan non bank yang berefek pada rendahnya kesadaran menabung, terjebak investasi palsu, tertipu pinjaman online ilegal, tidak memiliki tabungan pensiun, memiliki aset rendah dan berperilaku konsumtif dalam pengeluaran, maka perlu dicari solusinya supaya kalangan wanita memiliki literasi keuangan yang benar. Berbagai hasil riset yang dirangkum oleh Otorittas Jasa Keuangan menunjukkan pengaruh pentingnya literasi keuangan yang dimiliki individu dan rumah tangga. Individu yang memiliki literasi keuangan lebih siap melakukan perencanaan keuangan pribadi, sedangkan rumah tangga yang memiliki literasi keuangan yang rendah cenderung tidak memiliki perencanaan pensiun dan memiliki aset yang rendah (OJK, 2017).

Tidak adanya literasi keuangan akan mendorong individu berperilaku konsumtif. Hasil penelitian menunjukkan hubungan negatif antara perilaku konsumtif dengan literasi keuangan (Adzkiya, 2018). Riset tersebut membuktikan bahwa literasi keuangan yang rendah menyebabkan masyarakat menjalani perilaku konsumtif yang tidak memahami skala prioritas kebutuhan. Kebutuhan tersier cenderung menjadi primer dan sekunder. Padahal kecakapan literasi keuangan merupakan salah satu keterampilan yang penting dikuasai oleh masyarakat khususnya wanita di abad 21 ini. Sebagai contoh adalah kegiatan investasi yang ditawarkan sebuah lembaga Koperasi Simpan 
Pinjam di Depok pada tahun 2017 menyebabkan empat orang nasabahnya melakukan tindakan bunuh diri akibat tertekan dan mengalami kesulitan keuangan. Koperasi menawarkan investasi dengan profit $10 \%$ sehingga banyak masyarakat yang bergabung (Tribunnews.com, 2017).

Berdasarkan kenyataan tersebut, maka kegiatan pengabdian masyarakat ini mencoba memberikan solusi untuk mengatasi persoalan rendahnya literasi keuangan di kalangan wanita. Untuk mencari solusi atas rendahnya literasi keuangan di kalangan wanita, maka abdimas ini bertujuan untuk mengenalkan dan memberikan pemahaman tentang manajemen atau pengelolaan keuangan pribadi dan keluarga terkait konsep pengeluaran, menabung, berbagi untuk amal, dan berinvestasi. Manfaat abdimas ini adalah: untuk membantu program Otoritas Jasa Keuangan dalam meningkatkan literasi keuangan di kalangan wanita ibu-ibu rumah tangga, meningkatkan kesadaran, kemauan dan kecakapan ibu-ibu rumah tangga mengakses lembaga keuangan bank/non bank dan melakukan transaksi dengan lembaga tersebut dan manfaat terakhir yaitu keluarga yang memiliki ketahanan keuangan.

\section{METODE}

Kegiatan pengabdian masyarakat ini dilaksanakan pada tanggal 24 November 2019, bertempat di Posyandu Mawar RW 08 Kelurahan Abadijaya, Depok 2 Timur, Kecamatan Sukmajaya, Depok, Jawa Barat dengan peserta yang hadir 10 orang ibu-ibu rumah tangga yang berdomisili di RT 03 dan RT 07 RW 08. Peserta adalah wanita ibu rumah tangga rata-rata berusia paruh baya (Gambar 1).

\section{Teknik Pelaksanaan}

Tim pelaksana abdimas ini terdiri dari dua orang dosen dan satu orang mahasiswa (Gambar 2). Metode yanhg digunakan adalah ceramah interaktif antara tim sebagai pemateri dengan mitra sebagai peserta. Tim sebagai pemateri akan menggali informasi awal dari peserta tentang literasi keuangan yang selama ini telah dilakukan kemudian tim akan memberikan penjelasan terkait literasi keuangan yang bijak dan benar. Gambar 3 memperlihatkan

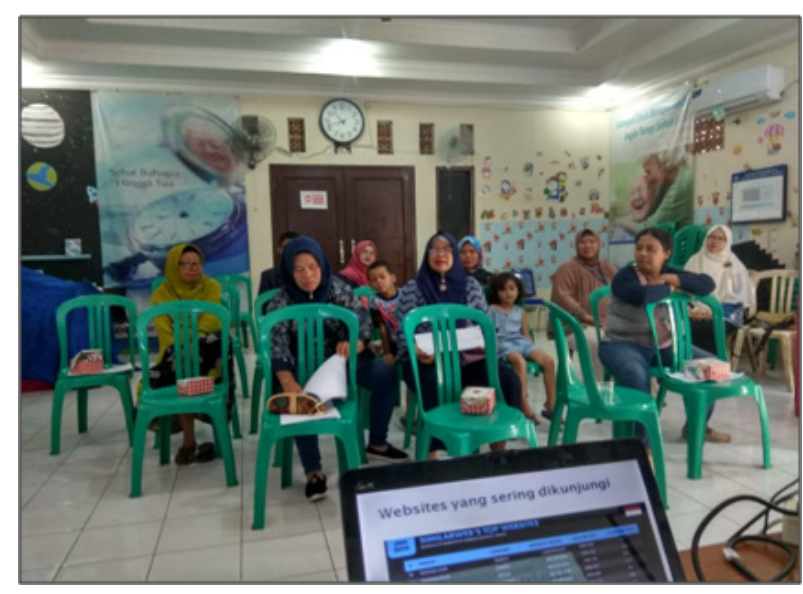

Gambar 1. Mitra Ibu-ibu Rumah Tangga

alur kegiatan dan target penyampaian materi abdimas mulai dari praabdimas, pelaksanaan, penyampaian pengelolaan keuangan rumah tangga yang akan membentuk perilaku keuangan ibu rumah tangga, selanjutnya perilaku keuangan yang sudah dipahami menjadi kecakapan literasi keuangan dan pada akhirnya diharapkan terbentuknya pemahaman bagaimana cara membangun ketahanan keuangan rumah tangga. Secara umum teknis kegiatan pengabdian masyarakat terbagi menjadi 2 bagian, antara lain:

1. Kegiatan praabdimas

Kegiatan praabdimas diawali dengan menggali informasi permasalahan umum literasi keuangan berdasarkan data-data survei OJK tahun 2016, 2019 dan berita di media massa. Kemudian dilakukan analisa perbandingan antara hasil survei OJK dan berita media massa dengan kondisi riil di lapangan.

2. Kegiatan saat abdimas

Pelaksanaan kegiatan pengabdian masyarakat berlangsung selama satu hari yang dibagi menjadi dua sesi, yaitu:

a) Penyampaian Materi (09.00 - 12.00 WIB)

Sesi pagi dimulai pukul 09.00 WIB sampai 12.00 WIB. Pada sesi penyampaian materi mitra dibekali pengetahuan tentang pengertian literasi keuangan, tujuan dan manfaat literasi keuangan, ruang lingkup, dan pengenalan masalah-masalah keuangan.

Warta LPM, Vol. 24, No. 3, Juli 2021 


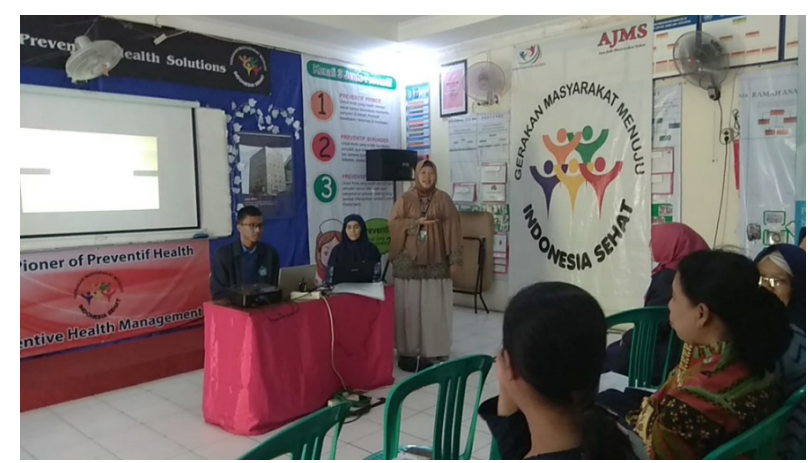

Gambar 2. Tim Abdimas sedang Menyampaikan Materi

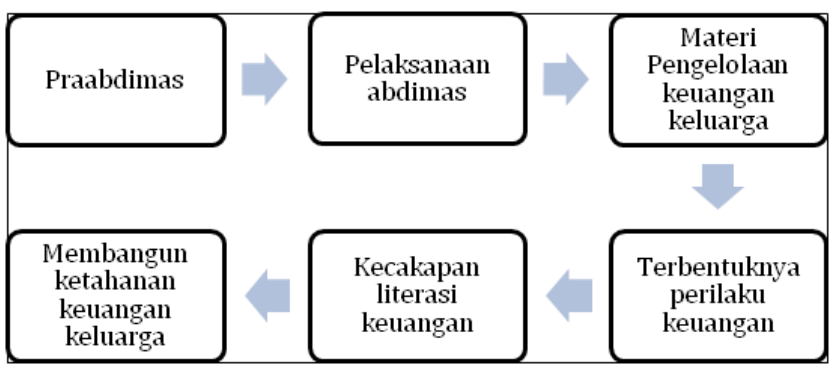

Gambar 3. Skema Alur Pelaksanaan Abdimas dan Target Penyampaian Materi

b) Interaktif Sesi (12.30 - 15.30 WIB)

Sesi ini dimulai setelah tim dan peserta istirahat selama 30 menit. Pada sesi ini, setelah informasi seputar literasi keuangan disampaikan maka pada sesi ini dilakukan penyampaian dan pendalaman materi dengan penjelasan yang langsung menyelesaikan persoalan keuangan mitra seputar membelanjakan pendapatan dengan bijak, menabung, mengenal investasi, perlindungan terhadap kesehatan, mencari pendapatan penunjang, memprioritaskan kebutuhan daripada gaya hidup.

\section{HASIL DAN PEMBAHASAN}

Pokok bahasan Pengenalan Literasi Keuangan dibagi menjadi dua yaitu materi pendahuluan dan materiinti. Materipendahuluan berisi pengertian, manfaat, ruang lingkup, dan pengenalan masalah-masalah keuangan yang umumnya dialami oleh kebanyakan masyarakat. Materi pendahuluan dijabarkan pada Tabel 1.

Materi pendahuluan sebagaimana dijabarkan dalam Tabel 1 disampaikan dengan tujuan supaya tertanam pengetahuan dasar tentang literasi keuangan secara umum. Selanjutnya disampaikan materi inti yang lebih

Tabel 1. Garis Besar Materi Pendahuluan

\begin{tabular}{lll}
\hline No & \multicolumn{1}{c}{ Materi } & \multicolumn{1}{c}{ Penjelasan } \\
\hline 1 & Pengertian & Pengetahuan dan kecakapan untuk mengaplikasikan \\
& & pemahaman tentang konsep dan risiko, keterampilan agar \\
dapat membuat keputusan efektif dalam konteks keuangan & untuk meningkatkan kesejahteraan individu maupun sosial \\
& & dan dapat berpartisipasi dalam lingkungan masyarakat
\end{tabular}


Tabel 2. Mengelola Keuangan Keluarga Secara Efektif

\begin{tabular}{cll}
\hline No & \multicolumn{1}{c}{ Pengelolaan Keuangan } & \multicolumn{1}{c}{ Penjelasan } \\
\hline 1 & Memaknai uang secara benar & $\begin{array}{l}\text { Uang bukan tujuan utama, uang hanya titipan, } \\
\text { sisihkan untuk donasi keagamaan/ziswaf } \\
\text { Menabung }\end{array}$ \\
2 & Mengendalikan pengeluaran & Menang \\
3 & Belanja sesuai kebutuhan bukan keinginan & Hindari utang konsumtif \\
4 & Bangun fondasi keuangan yang kuat & Dana pengaman jika berhenti bekerja karena Putus \\
& & Hubungan Kerja (PHK), asuransi PHK, asuransi \\
& & kesehatan \\
5 & Sisihkan dana 3P & Papan, pendidikan, pensiun \\
6 & Mengembangkan harta & Investasi, wirausaha \\
\hline
\end{tabular}

mengacu pada tuntunan dan langkah-langkah mengelola keuangan keluarga supaya tercapai ketahanan keuangan individu dan keluarga. Materi inti dibagi menjadi dua bagian. Bagian pertama tentang bagaimana mengelola keuangan keluarga secara efektif diperlihatkan pada Tabel 2 (Ning, 2015).

Dari Tabel 2 tentang bagaimana mengelola keuangan keluarga secara efektif diharapkan akan menuntun para ibu rumah tangga supaya memahami pengelolaan keuangan keluarga yang tepat. Pengelolaan keuangan keluarga yang demikian akan menuntun perilaku yang bijak dan benar saat mengalokasikan dan membelanjakan uang, yang tidak hanya sekedar memenuhi kebutuhan sehari-hari, tetapi terkait dengan persiapan dana untuk masa depan seperti dana tabungan pendidikan anak, dana tabungan pensiun, perlindungan/asuransi diri, dan harta benda. Pengelolaan keuangan yang tepat juga akan menghindarkan diri dan keluarga dari masalah-masalah keuangan yang lazim di masyarakat seperti pembelanjaan yang berlebihan, menunda menabung, kredit konsumtif atau tergiur investasi ilegal. Apabila pengelolaan keuangan keluarga ini dijalankan secara efektif akan mendorong peningkatan transaksi pada lembaga keuangan bank/non bank. Pada akhirnya akan menggerakkan perekonomian masyarakat. Materi inti bagian kedua adalah langkah-langkah untuk mencapai ketahanan keuangan seperti dipaparkan pada Tabel 3 berikut:

Tabel 3. Langkah-Langkah Membangun Ketahanan Keuangan Keluarga

\begin{tabular}{|c|c|c|}
\hline No & Langkah-langkah & Penjelasan \\
\hline 1 & $\begin{array}{l}\text { Tujuan keuangan harus } \\
\text { fokus dan jelas }\end{array}$ & $\begin{array}{l}4 \text { tujuan keuangan : } \\
\text { 1. Bertahan hidup } \\
\text { 2. Kestabilan } \\
\text { 3. Kesuksesan untuk keluarga } \\
\text { 4. Kesuksesan untuk lingkungan sekitar }\end{array}$ \\
\hline 2 & Inventarisasi keuangan & $\begin{array}{l}\text { 1. Buat neraca keuangan : } \\
\text { a. Tentukan aset dan kewajiban } \\
\text { b. Tentukan kekayaan bersih (aset-utang) } \\
\text { 2. Buat arus kas untuk mengetahui aliran pemasukan dan } \\
\text { pembelanjaan per bulan }\end{array}$ \\
\hline 3 & $\begin{array}{l}\text { Skala prioritas } \\
\text { pembelanjaan }\end{array}$ & $\begin{array}{l}\text { 1. Donasi untuk Tuhan Sang Pencipta, misalkan } 2.5 \% \text { ziswaf } \\
\text { 2. Lunasi utang konsumtif } \\
\text { 3. Persiapkan dana untuk masa depan yaitu } 30-40 \% \text { papan, } \\
\text { pendidikan, } 10 \% \text { pensiun, asuransi kesehatan, dana darurat } \\
\text { 4. Berinvestasi atau berwirausaha } \\
\text { 5. Memenuhi kebutuhan tersier (kesenangan/ kemewahan) }\end{array}$ \\
\hline
\end{tabular}


Melalui Tabel 3 diperlihatkan kepada mitra perlunya bagi mereka membuat perencanaan keuangan keluarga supaya diketahui posisi kekayaan bersih dan arus kas pemasukan dan pengeluaran setiap bulannya sehingga dapat diketahui bagaimana aliran keuangan keluarga yang sehat. Melalui perencanaan dan pengelolaan keuangan yang tepat akan diketahui skala prioritas pembelanjaan sesuai kebutuhan yang benar mulai dari memenuhi kebutuhan primer (sandang, pangan, dan papan), sekunder dan tersier. Dengan demikian diharapkan muncul sikap dan perilaku keuangan yang benar dalam mengalokasikan dan membelanjakan pendapatan baik individu maupun keluarga, sehingga diharapkan perilaku konsumtif bisa berganti menjadi sikap yang bijak dalam membelanjakan uangnya.

Materi inti yang kedua ini fokus mengajak mitra ibu-ibu rumah tangga supaya pandai merencanakan dan mengelola keuangan keluarga supaya terwujud ketahanan keuangan keluarga. Mengingat peran wanita dalam rumah tangga sebagai manajer keuangan keluarga yang harus terampil membuat perencanaan dan pengelolaan keuangan keluarga. Keluarga dengan ketahanan keuangan yang kuat lebih baik jika dibandingkan dengan keluarga dengan ketahanan keuangan yang rapuh. Materi ini mendukung program strategis Otoritas Jasa Keuangan bagian kedua tentang upaya membangun ketahanan keuangan keluarga yang kuat apabila ada goncangan ekonomi.

Suatu materi dipandang menarik dan memiliki nilai tambah bagi mitra dapat diketahui dari respon balik mereka setelah mendapatkan penjelasan materi tersebut. Respon dari mitra berupa pertanyaan-pertanyaan persoalan keuangan sehari-hari yang belum dapat ditangani oleh mereka. Permasalahan keuangan yang mereka alami adalah persoalan keuangan anakanak mereka yang belum paham pengaturan dan perencanaan keuangan yang bijak sehingga terjebak perilaku konsumtif. Anak-anak mereka ada yang berstatus mahasiswa, pelajar dan pekerja lajang yang belum bisa mengontrol pembelanjaan ketika anak-anak mereka memegang uang. Ada tiga pertanyaan yang diajukan:

a. Bagaimana menyadarkan sang anak yang berstatus mahasiswa untuk bisa mengatur keuangan secara benar? Karena orang tua tidak menginginkan sang anak terjebak perilaku konsumtif.

b. Anak mendapatkan beasiswa namun uang saku yang diperoleh digunakan untuk pembelanjaan yang tidak diperlukan. Bagaimana menyadarkan sang anak supaya bersikap bijak mengalokasikan dan membelanjakan uang sesuai prioritas yang benar?

c. Anak masih lajang memiliki usaha skala mikro, namun modal usaha selalu digunakan untuk pembelanjaan yang tidak sesuai alokasi usaha. Padahal orang tua menginginkan modal usaha ditabung untuk digunakan menambah modal usaha. Namun sang anak tidak melakukan pembelanjaan dengan bijak, usaha yang dijalankan tidak fokus sehingga terkesan tidak serius dijalankan. Bagaimana menyadarkannya?

Dari tiga keluhan yang disampaikan oleh mitra ibu-ibu rumah tangga, terdapat kesamaan persoalan yang dikeluhkan yaitu kecenderungan perilaku pembelanjaan yang tidak sesuai kebutuhan, dominan keinginan yang membuat keengganan menyisihkan uang untuk keperluan lain yang lebih penting dan darurat. Adapula yang tidak paham skala prioritas pembelanjaan yang menggunakan keuntungan dari usaha untuk alokasi pembelanjaan yang tidak tepat, sehingga usaha yang dijalankan akhirmya tidak maju dan berkembang. Persoalan tersebut sejalan dengan hasil penelitian yang menemukan bahwa gaya hidup dan uang saku mempengaruhi perilaku konsumsi di kalangan mahasiswa terhadap barang non makanan (Azis, 2019). Artinya terdapat kecenderungan perilaku konsumtif ketika anak mendapatkan uang saku ditambah juga dengan gaya hidup sekitar yang ikut mendorong pembelanjaan tidak sesuai kebutuhan.

Anak-anak mereka yang berstatus pelajar, mahasiswa, dan pemuda yang masih lajang termasuk kelompok yang menjadi target program strategis nasional literasi keuangan Otoritas Jasa Keuangan. Persoalan keuangan anak-anak mereka adalah bagian dari persoalan keuangan keluarga. Oleh sebab itu, para ibu rumah tangga perlu memberikan pemahaman bagaimana konsep uang dan cara 
membelanjakannya supaya muncul dalam diri anak keterampilan dalam mengambil keputusan keuangan yang tepat bagi kehidupan anak di masa depan. Karena sikap dan perilaku yang demikian merupakan sikap dan perilaku yang berisiko tinggi jika menghadapi goncangan keuangan seperti sakit keras, diberhentikan dari pekerjaan, pasangan yang berperan mencari nafkah meninggal dunia, usaha bangkrut, tertipu investasi yang tidak benar atau tekanan ekonomi yang sulit seperti wabah Covid 19 yang melanda seluruh dunia pada tahun 2020 dan masih berlanjut pada tahun 2021 .

Tekanan atau goncangan ekonomi berpeluang menurunkan kesejahteraan dan kualitas hidup. Sebuah penelitian menunjukkan bahwa tekanan ekonomi menurunkan kualitas hidup sebuah keluarga (Kumalasari \& Herawati, 2018). Misalnya ditelantarkannya anak dan keluarga. Keadaan demikian berakibat pada ketidakharmonisan, perceraian, kekerasan dalam rumah tangga, depresi, sakit jiwa, dan lainnya. Seperti kasus di Depok pada lembaga koperasi dengan modus investasi terungkap setelah Otoritas Jasa Keuangan menginvestigasi kegiatan koperasi simpan pinjam yang dinilai telah merugikan nasabahnya. Mereka tergiur dengan imbalan profit $10 \%$ atas hasil investasinya. Lembaga keuangan tersebut menjalankan model investasi dengan skema Ponzi, yaitu dana yang masuk dari satu investor akan digunakan untuk membayar profit sebesar $10 \%$ untuk investasi yang ditanamkan oleh investor yang lain. Demikian seterusnya sampai akhirnya koperasi gagal membayarkan profit $10 \%$ yang dijanjikan. Akibatnya terdapat beberapa individu yang mengalami stres dan bunuh diri karena uang yang diinvestasikan tidak kembali seperti yang dijanjikan. Secara ringkas persoalan keuangan yang diperoleh saat pelaksanaan abdimas dan juga solusinya dapat dilihat pada Tabel 4.

Berdasarkan diskusi akhir tersebut dapat diketahui bahwa penguatan dan pengelolaan keuangan keluarga menjadi penting dipahami oleh ibu rumah tangga karena pengetahuan tersebut menjadi dasar terbentuknya literasi keuangan. Salah satu kecakapan yang akan terbentuk adalah sikap dan perilaku saat mengambil keputusan terkait persoalan keuangan. Kecakapan ini penting dimiliki ibu rumah tangga karena akan mempengaruhi literasi keuangan keluarga khususnya sikap dan perilaku keuangan anak-anak mereka (Gambar 4). Sebuah riset menyatakan bahwa pengelolaan keuangan keluarga dipengaruhi secara positif oleh beberapa faktor antara lain faktor pengetahuan keuangan meski tidak begitu signifikan dan sikap keuangan yang signifikan (Yulistia, 2018).

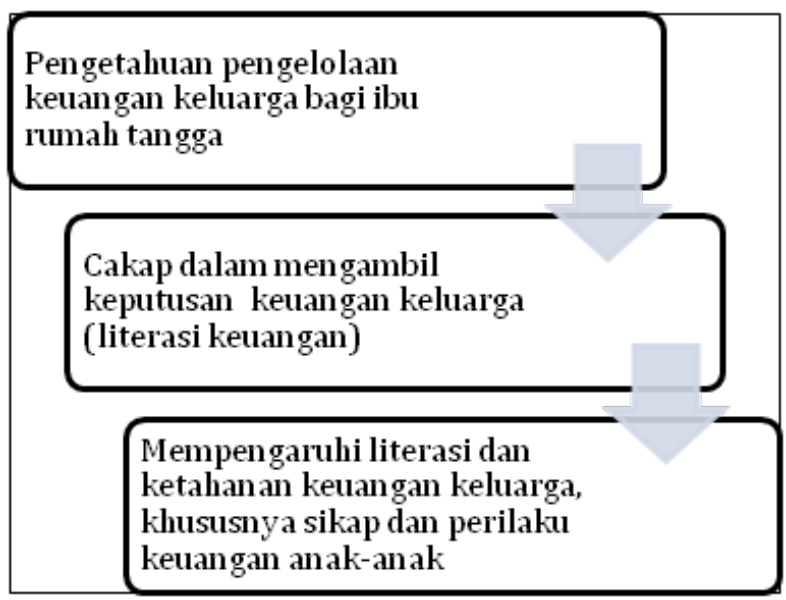

Gambar 4. Pentingnya Literasi Keuangan Bagi Ibu Rumah Tangga

Tabel 4. Persoalan Keuangan dan Solusinya

Keluhan-keluhan

Pembelanjaan yang berlebihan
1. Memahami uang scara benar bahwa uang hanya titipan yang bersifat sementara.

2. Perlunya displin personal dengan menyisihkan uang untuk ditabung guna mengantisipasi kejadian tak terduga.

3. Menyisihkan uang untuk kegiatan amal yang positif seperti ziswaf

Tidak memahami skala prioritas Membuat perencanaan dan pengelolaan keuangan secara tepat pembelanjaan melalui neraca keuangan dan arus kas sehingga akan diketahui pos-pos kebutuhan primer, sekunder dan tersier 
Literasi keuangan berpengaruh signifikan terhadap ketahanan keuangan seseorang ketika menghadapi krisis ekonomi atau goncangan dalam kehidupan ekonomi (Hassan, Kassim, \& Ma'on, 2018). Sejalan dengan hasil penelitian itu, abdimas ini berupaya untuk membuat mitra memiliki ketahanan keuangan individu dan keluarga. Demikian pula dengan penghasilan yang diperoleh bukan termasuk faktor yang menentukan ketahanan keuangan keluarga menurut McKnight (2018), namun pengetahuan keuangan yang memadai akan membuat pengambilan keputusan ketika menghadapi goncangan dan tekanan ekonomi akan lebih mudah dilakukan karena telah memiliki pemahaman utuh dan benar akan makna uang, perilaku konsumsi yang sesuai kebutuhan, pengalokasian keuangan yang tepat dan bijak untuk pengeluaran sehari-hari dan masa depan. Dengan demikian abdimas ini sangat bermanfaat untuk membentuk sikap dan perilaku keuangan ibu-ibu rumah tangga yang selanjutnya akan mempengaruhi sikap dan perilaku keuangan anak-anak mereka. Sebuah riset menguatkan hasil abdimas ini bahwa pendidikan keuangan yang didapatkan oleh seorang mahasiswa dalam lingkungan keluarganya berpengaruh positif terhadap perilaku pengelolaan atau manajemen keuangan pribadinya (Arifa, 2019).
Karena literasi keuangan termasuk salah satu indikator yang menentukan ketahanan keuangan ketika menghadapi tekanan ekonomi atau goncangan keuangan keluarga, maka setelah tanya-jawab berlangsung, tim mencoba mengetahui pemahaman mitra tentang dasardasar literasi keuangan dengan menyebarkan angket (Tabel 5).

Melalui tabel di atas pemahaman dasardasar keuangan mitra ibu rumah tangga terlihat belum memahami neraca keuangan dan arus kas serta pengetahuan investasi. Pemahaman posisi pos-pos aset dan kewajiban adalah dasar dalam penentuan skala prioritas membuat perencanaan anggaran pembelanjaan dan berinvestasi. Mengingat para peserta abdimas ini adalah para ibu rumah tangga yang berusia paruh baya maka sesuai dengan sebuah hasil penelitian yang menyatakan semakin bertambah usia suami istri dalam rumah tangga maka semakin rendah manajemen keuangan keluarga tersebut (Fajrin, 2011). Pengelolaan atau manajemen keuangan keluarga adalah kemampuan keluarga mengelola sumber daya keuangan yang dimiliki untuk memenuhi kebutuhan sehari-hari yang terdiri dari perencanaan, pelaksanaan dan evaluasi keuangan keluarga (Maesaroh, 2015). Ini menunjukkan pengetahuan dan sikap terkait pengelolaan keuangan rumah tangga semakin rendah dengan bertambahnya usia mereka.

Tabel 5. Pemahaman Mitra tentang Dasar-dasar Literasi Keuangan

\begin{tabular}{llccc}
\hline \multirow{2}{*}{ No } & \multicolumn{1}{c}{ Indikator Literasi Keuangan Sederhana } & \multicolumn{2}{c}{ Jawaban } & \multirow{2}{*}{ Jumlah } \\
\cline { 2 - 4 } & Benar & Salah & \\
\hline 1. & Fungsi uang sebagai alat tukar & 10 & 10 \\
2. & $\begin{array}{l}\text { Mengerti definisi kebutuhan primer, sekunder, dan tersier dalam } \\
\text { memenuhi kebutuhan sehari-hari }\end{array}$ & 6 & 4 & 10 \\
3. Mengetahui skala prioritas dalam berbelanja & 5 & 5 & 10 \\
4. Mengetahui tentang neraca keuangan sederhana dan arus kas & 1 & 9 & 10 \\
5. Mengetahui perencanaan keuangan rumah tangga & 6 & 4 & 10 \\
6. Pemahaman tentang menabung di bank dan produk/jasa bank & 9 & 1 & 10 \\
7. Pemahaman tentang investasi dan produk investasi & 4 & 6 & 10 \\
8. Mengetahui tentang pengajuan kredit di bank dan non bank & 7 & 3 & 10 \\
9. Memiliki asuransi (kesehatan, pensiun, dan jiwa) & 6 & 4 & 10 \\
10. Pemahaman tentang kejahatan keuangan & 7 & 3 & 10 \\
11. Pengetahuan mengakses informasi keuangan & 6 & 4 & 10 \\
\hline
\end{tabular}


Walau demikian abdimas ini telah membuka pemikiran mereka para ibu rumah tangga berusia paruh baya tersebut tentang pentingnya memiliki literasi keuangan apalagi literasi keuangan yang akan mereka ajarkan kepada anak-anak mereka. Indikasinya adalah munculnya keluhan-keluhan mereka seputar perilaku dan sikap keuangan anak-anak mereka saat memegang uang. Walaupun abdimas hanya dilaksanakan satu hari dan tentu saja itu tidaklah cukup untuk mengubah sikap dan perilaku mereka hanya dalam sehari, namun yang terpenting adalah bahwasanya mereka minimal memiliki dasar pemahaman dan kesadaran dalam menyikapi, mengatur, mengelola dan membelanjakan uang dengan bijak.

\section{SIMPULAN}

Pelaksanaan pengabdian masyarakat direspon positif oleh ibu-ibu rumah tangga yang diperlihatkan dengan munculnya kesadaran dan keinginan mereka agar anak-anak mereka yang berstatus mahasiswa, pelajar, dan pemuda lajang memiliki sikap dan perilaku yang bijak terhadap persoalan keuangan yang dialami anak-anaknya antara lain pembelanjaan berlebihan, belum membuat perencanaan dan pengelolaan keuangan, belum memahami skala prioritas kebutuhan dalam membelanjakan uang dan perilaku konsumtif yang lebih cenderung mementingkan keinginan daripada kebutuhan. Sikap dan perilaku demikian berisiko merugikan ketika terjadi tekanan ekonomi atau goncangan keuangan. Dengan demikian materi abdimas yang disampaikan mulai dipahami oleh mereka sehingga timbul diskusi pada sesi akhir pelaksanaan abdimas. Abdimas ini perlu ditindak lanjuti dengan topik pembekalan bagi mereka untuk memahami praktek perencanaan dan pengelolaan keuangan keluarga supaya terampil membuat skala prioritas kebutuhan primer, sekunder, dan tersier supaya mereka mampu menghadapi ketahanan keuangan keluarga.

\section{PERSANTUNAN}

Tim mengucapkan terima kasih banyak kepada pengurus RW 08 Kelurahan Abadijaya dan ibu-ibu rumah tangga RT 03 dan RT 07 yang telah berpartisipasi dalam kegiatan pengabdian masyarakat ini dan LPPM Universitas Indraprasta PGRI Jakarta yang telah menerbitkan surat tugas abdimas sehingga kegiatan tersebut dapat terlaksana.

\section{REFERENSI}

Adzkiya, A. (2018). Analisis Perilaku Konsumtif dan Faktor Pendorongnya (Studi Kasus Mahasiswa Universitas Islam Negeri Syarif Hidayatulah Jakarta Angkatan 2017)). Jakarta: Skripsi Fakultas Ekonomi dan Bisnis.

Arifa, N. S. (2019).Pengaruh Pendidikan Keuangan di Keluarga, Pendapatan dan Literacy Keuangan terhadap Financial Management Behaviour melalui Financial Self-Efficacy sebagai Variabel Mediasi pada Mahasiswa Universitas Negeri Semarang Tahun Angkatan 2016. Semarang: Skripsi, Fakultas Ekonomi, Universitas Negeri Semarang.

Azis, I. (2019). Pengaruh Uang Saku, Gaya Hidup, dan Perilaku Menabung terhadap Pola Konsumsi Non Makanan Mahasiswa. Jurnal Ilmiah Mahasiswa FEB, 8(1) Universitas Brawiijaya.

Fajrin, F. (2011). Manajemen Keuangan dan Kesejahteraan Keluarga Perempuan Buruh Pabrik di Kabupaten Bogor. Bogor: Skripsi, Fakultas Ekologi Manusia, Institut Pertanian Bogor.

Hassan, N. M., Kassim, E. S., \& Ma'on, S. N. (2018). Factors Influencing Individual Financial Resilience in Facing Economic Crisis: Does Financial Literacy Really Help? International Journal of Academic Research in Business and Social Sciences, 8(11), 1613-1623.

Kemendikbud. (2017). Gerakan Literasi Finansial. In K. P. Kebudayaan, Materi Pendukung Literasi Finansial (p. 41). Jakarta: Kemendikbud. 
Lindiawatie dan Shahreza - Penyuluhan Literasi Keuangan pada Ibu Rumah Tangga ...

KPPPA. (2016). Pembangunan Ketahanan Keluarga. Jakarta: Kementerian Pemberdayaan Perempuan dan Perlindungan Anak.

Kumalasari, B., \& Herawati, T. d. (2018). Relasi Gender, Tekanan Ekonomi, Manajemen Keuangan, Strategi Nafkah dan Kualitas Hidup pada Keluarga Nelayan. Jurnal Ilmu Keluarga dan Konsumen, 11(2), 108-119,

Maesaroh, S. (2015). Tekanan Ekonomi, Manajemen Keuangan Keluarga dan Ketahanan Fisik Ekonomi Keluarga di Pemukiman Marjinal. Bogor: Skripsi, Fakultas Ekologi Manusia, Institut Pertanian Bogor.

McKnight, A. (2018). Financial Resilience: Measures, Trends and Policy Options. Brussel: Centre of Analysis of Social Exclusion.

Ning, L. T. (2015). 6 Keranjang, 7 Langkah Api. Jakarta: PT Gramedia Pustaka Utama.

OJK. (2016). Survei Nasional Literasi dan Inklusi Keuangan. Jakarta: Otoritas Jasa Keuangan.

OJK. (2017). Strategi Nasional Literasi Keuangan Indonesia (Revisit 2017). Jakarta: Otoritas Jasa Keuangan.

OJK. (2019). Survei Nasional Literasi dan Inklusi Keuangan . Jakarta: Otoritas Jasa Keuangan.

Potrich, A., Viera, M., \& Kirch. (2014). Determinants of Financial Literacy: Analysis of the Influence of Socioeconomic and Demographic Variables. Revista Contabilidade \& Finanças, Pages 362-377.

Rahmayanti, W., Nuryani, H. S., \& Salam, A. (2019). Pengaruh Sikap Keuangan dan Perilaku Keuangan terhadap Literasi Keuangan (Studi Kasus pada Ibu Rumah Tangga di Desa Lito .Jurnal Manajemen dan Bisnis, 2(1).

Salignac, F, Marjolin, A., \& Reeve, R. M. (2019). Conceptualizing and Measuring Financial Resilience : A Multidimensional Framework. Social Indicator Research : An International and Interdiciplinary Journal for Quality of Life Measurement, 145(2), 17-38.

Sihombing, A., Rahardja, A. A., \& Gabe, R. T. (2020). The Role of Millennial Urban Lifestyles in the Transformation of Kampung Kota in Indonesia. Environment and Urbanization Asia, II (I) 155169.

Suyanto, B., Sugihartati, R., Hidayat, M., \& Subiakto, H. (2020). Global vs Local: Lifestyle and Consumption Behaviour Among the Urban Middle Class in East Java, Indonesia. South East Asia Research, Pages 398-417.

Tribunnews.com. (2017, Juli 18). Stres Kesulitan Keuangan, 4 Nasabah KSP Pandawa Bunuh Diri. www. tribunnews.com/metropolitan: www.tribunnews.com

Yulistia, R. (2018). Faktor-faktor yang Mempengaruhi Perilaku Pengelolaan Keuangan Keluarga di Kabupaten Tuban. Surabaya: Sekolah Tinggi Ilmu Ekonomi Perbanas. 